\title{
Variability of tree transpiration across three zones in a southeastern U.S. Piedmont watershed
}

\author{
Johnny Boggs ${ }^{1}$, Ge Sun ${ }^{1}$, Jean-Christophe Domec ${ }^{2}$, and Steven McNulty ${ }^{1}$ \\ ${ }^{1}$ USDA Forest Service Southern Research Station \\ ${ }^{2}$ Duke University Nicholas School of the Environment
}

April 29, 2021

\begin{abstract}
Quantifying species-specific tree transpiration across watershed zones is important for estimating watershed evapotranspiration (ET) and predicting drought effects on vegetation. The objectives of this study are to 1) assess sap flux density (Js) and tree-level transpiration (Ts) across three contrasting zones (riparian buffer, mid-hillslope, and upland-hillslope), 2) determine how species-specific Js responds to vapor pressure deficit (VPD), and 3) compare watershed-level transpiration (Tw) derived from each zone. We measured Js and Ts in eight tree species in the three zones in a 12-ha forested watershed. In the dry year of 2015, loblolly pine (Pinus taeda), Virginia pine (Pinus virginiana), and sweetgum (Liquidambar styraciflua) Js rates were significantly higher in the buffer when compared to the other two zones. In contrast, Js in tulip poplar (Liriodendron tulipifera) and red maple (Acer rubrum) were significantly lower in the buffer than in the mid-hillslope. Daily Ts varied by zone and ranged from 10 to 93 liters in the dry year and 9 to 122 liters in the wet year. Js responded nonlinearly to VPD in all trees and zones. Annual Tw based on scaled-Js data was $447 \mathrm{~mm}, 377 \mathrm{~mm}$, and $340 \mathrm{~mm}$ for the buffer, mid-hillslope, and upland-hillslope, respectively. We conclude that large spatial variability in Js and scaled Tw were driven by differences in soil moisture at each zone and forest composition. Consequently, spatial heterogeneity of vegetation and soil moisture must be considered when accurately quantifying watershed level ET.
\end{abstract}

\section{INTRODUCTION}

About 50-75\% of annual precipitation that falls in southern forests in the U.S. returns the atmosphere through the process of evapotranspiration (ET), the sum of tree transpiration, canopy interception, and soil evaporation (Sun et al., 2001; Sun et al., 2016). Natural (e.g. climate change and variability, drought) and anthropogenic stressors (e.g. land use change, urbanization), and forest management (e.g., thinning, prescribed burning) affect water quantity and water quality, and ecosystem productivity (Sun et al., 2011) by directly altering forest transpiration process, a key component of ET in forests (Domec et al., 2012). Water use by trees or stand is naturally variable due to the large differences in tree species, age, stand structure (leaf area index), and climate (Sun et al., 2011). Given the issues with landcover change, urbanization, and an increase in extreme events from climate change facing the Piedmont region in the U.S. (Wear and Greis, 2013), an improved understanding of tree transpiration at the species level within a forested watershed is needed. Such information is useful for developing foundational steps toward improving watershed-level estimates of transpiration in mixed forests and reliable ecohydrological model to predict the effects of environmental change on water and carbon resources (Liu et al., 2020; Li et al., 2020a, 2020b).

Land use change and fire regimes have produced highly variable species composition in the U.S. southeastern Piedmont. The region supports about 12.5 million hectares of forest land or $62 \%$ of the total land area, with $52 \%$ of forest lands covered by upland hardwoods and $34 \%$ by pines (Rummer and Hafer, 2014). The upland hardwood forest types consist of a mixture of white oak (Quercus alba), red oak (Quercus rubra), hickories 
(Carya spp. ), sweetgum (Liquidambar styraciflua), and tulip poplar (Liriodendron tulipifera). The oakpine forest type is dominated by loblolly (Pinus taeda), Virginia (Pinus virginiana) and shortleaf (Pinus Echinata) pines, and southern red oak (Quercus falcata). Although many state and federal regulatory agencies require forests in the source water supply zone of a watershed be protected to slow runoff and maintain minimal discharge levels, $17 \%$ of total forest area could be lost by 2060 due to high urbanization and low timber prices with most of the losses occurring in the upland hardwood (Rummer and Hafer, 2014). Given the variability in species transpiration, the type of trees removed from the landscape will likely impact soil moisture, streamflow in headwater catchments, and downstream water supply (Moore et al., 2004; Swank and Vose, 1994).

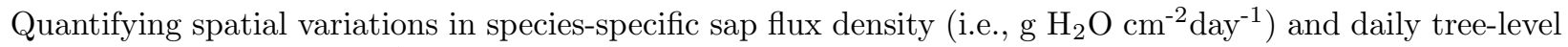
transpiration (i.e., $\mathrm{kg} \mathrm{day}^{-1}$ or liters day ${ }^{-1}$ ) is essential to improve stand-scaled transpiration estimates and total ET at the watershed level. Sap flux density and transpiration rates can vary widely by species (Boggs et al., 2015; Yi et al., 2017). For example, tree transpiration in a temperate pine-hardwood riparian buffer forest can range from 2 to 142 liters day $^{-1}$ and can increase nonlinearly with increasing tree diameter (Bosch et al., 2014). Transpiration can vary across plant species due to tree xylem structure (Ford et al., 2011), responses to vapor pressure deficit (VPD) (Moore et al., 2017), and age (Brantley et al., 2019). Tulip poplar, a species with diffuse porous xylem and large amount of sapwood, can use up to three-fold more water than oaks (Quercus spp. ), a species with a narrow sapwood characterized by a ring porous structure (Ford et al., 2011).

Species level transpiration can also differ across topography or zones due to landscape level variations in microclimate and soil moisture (Emanuel et al., 2010; 2011). Hawthorne and Miniat (2016) found that transpiration per unit leaf area in hickory species was sensitive to the topographic position during a wet year, producing $56 \%$ less water at a cove site when compared to an upland site. However, chestnut oak (Quercus prinus ) decreased $41 \%$ from a wet year to a dry year but was not influenced by topographic position. Bosch et al. (2014) also found that species topographical position does not consistently influence tree transpiration rates across species.

At the stand level, linking species transpiration and soil moisture helps further refine watershed-level estimates of transpiration (Oishi et al., 2010) and improve our understanding of how forests respond to water stresses, including drought (Vose et al., 2016, Yi et al., 2017). Sap flux density and tree-level transpiration measurements have advanced dramatically during the last decade (Poyatos et al., 2020). However, questions are still being raised about how to improve watershed-level transpiration, given the variations in species composition, topography, and soil moisture. In addition, variability in tree transpiration across heterogeneous watersheds is typically not considered (or well captured) by models and may be one contributing factor to over or under predictions of water loss from the forest at local and regional scales. Therefore, the objectives of this study are to 1) quantify tree sap flux density and transpiration across three zones (riparian buffer, mid-hillslope, and upland-hillslope) in a wet and dry year, 2) analyze the relationships between sap flux density and vapor pressure deficit, and 3) compare watershed-level transpiration derived from three zones.

\section{MATERIALS AND METHODS}

\subsection{Study site}

The watershed in this study, designated as Hill Forest Two (HF2), is characterized as a 38-year-old mixed pine-hardwood stand located within the Piedmont region of North Carolina (NC) (Figure 1). The catchment drains the first-order streams in the large Flat River watershed at North Carolina State University's Hill Demonstration Forest in northern Durham County, NC. HF2 is 12 hectares in size, and dominated by loblolly pine (Pinus taeda), white oak (Quercus alba), tulip poplar (Liriodendron tulipifera), sweetgum (Liquidambar styraciflua), chestnut oak (Quercus prinus), Virginia pine (Pinus virginiana), northern red oak (Quercus rubra), red maple (Acer rubrum), American beech (Fagus grandifolia), pignut hickory (Carya glabra), and mockernut hickory (Carya tomentosa). Upland soils are defined as well-drained with a depth to the water table higher than two meters $(\mathrm{m})$. They tend to function in a similar drainage capacity in 
the growing season (i.e., May-October) and non-growing season (i.e., November-April). The NC Geological Survey (1988) reported that the soil substrate (Carolina Slate Belt, CSB) is comprised mostly of rocks formed through volcanic activity and deposits. The total land surface in CSB covers $9 \%$ of NC and extends into the surrounding states of Virginia and South Carolina (Cleland et al., 2007). The soil series is mainly comprised of Tatum and Appling types. Additional soil and watershed descriptive details can be found in Boggs et al. $(2013,2016)$.

\subsection{Micrometeorology and soil moisture}

Meteorological data have been monitored in this watershed since 2007 as part of a Best Management Practice (BMP) project (Boggs et al., 2015; 2016). Precipitation was measured in an open area with a Hobo DataLogging Rain Gauge - RG3 (Onset Corporation, Bourne, MA, USA) approximately $450 \mathrm{~m}$ from the farthest sap flux station. Relative humidity $(\mathrm{RH})$ and air temperature measurements were recorded with a Hobo Micro Station (Onset Corporation, Bourne, MA) next to the rain gauge every 10 minutes and averaged every hour. The hourly vapor pressure deficit (VPD) was calculated from RH and air temperature data and reported in kilopascals $(\mathrm{kPa})$.

Soil moisture and sap flux density were measured in the riparian buffer, mid-hillslope, and upland-hillslope zones of the watershed from May 2015 to December 2016. The definition of the riparian buffer was based on field observations of sandy loam soils in the flat (i.e., $<12 \%$ slope) stream valley bottom (Dreps et al., 2014). Mid-hillslope units correspond with the Tatum soil series and are on relatively steep (i.e., 12-50\%) slopes with eroded soils that have a shallow depth to bedrock. Shallow-to-deep water tables and upland-hillslope units are relatively flat slopes on deep soils that correspond to Cecil, Appling, and Georgeville soil series (Dreps et al., 2014). Volumetric soil moisture $\left(\mathrm{m}^{3} \mathrm{~m}^{-3}\right.$ or \%) readings were taken using a water content reflectometer (CS 615; Campbell Scientific, Logan, UT, USA). Two reflectometers were installed at each zone near the sap flux monitored trees. The reflectometers were inserted parallel to the ground surface at 10 and $30 \mathrm{~cm}$ depths in the riparian buffer, and at 10 and $60 \mathrm{~cm}$ depths in the mid-hillslope and upland-hillslope. Soil moisture data were logged every 10 minutes using a CR1000 datalogger (Campbell Scientific, Logan, UT, USA).

\subsection{Vegetation survey}

Sixteen 10-meter radius survey plots were established in 2015 to quantify diameter at breast height (dbh) and stem density of trees in the mid-hillslope and upland-hillslope. Four $152 \mathrm{~m}^{2}$ plots were used to assess trees in the riparian buffer (Boggs et al., 2016). We did not used the 10-meter radius sampling design that was used in the mid-hillslope and upland-hillslope zones for the riparian buffer because it would have stretched beyond the boundary of the 15.2-meter wide buffer. Therefore, rectangular-shaped plots were used to characterize the overstory vegetation in the buffer (Figure 1).

Tree diversity of the watershed in this study was composed of loblolly and Virginia pines, and several native hardwoods (Table 1). The area covered by these species varied across the watershed with loblolly pine, red maple, sweetgum, and tulip poplar having higher densities in the riparian buffer than in other zones. The

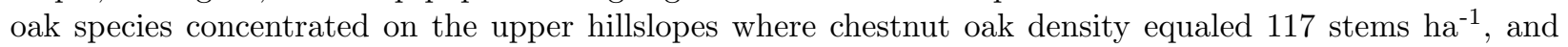
white oak density equaled $85 \mathrm{stems} \mathrm{ha}^{-1}$. Species sapwood area represented $86 \%$ of the basal area in the monitored trees in the buffer, $72 \%$ in the mid-hillslope, and $74 \%$ in the upland-hillslope. Sapwood area in oak species represented the smallest percentage of the basal area when compared to the other trees, averaging $47 \%$, while loblolly pine averaged $91 \%$.

\subsection{Sapwood area}

An increment borer was used to extract two wood cores from 18 trees in the riparian buffer zone, 19 trees in the mid-hillslope, and 15 trees in the upland-hillslope. All the tree core samples were collected adjacent to, but outside of the survey plots and sap flux stations. The amount of sapwood from each core was measured with a ruler in the lab and linked to the species stem density and dbh data to derive sapwood area in the monitored trees in the sap flux stations and sapwood area in the trees in the survey plots (Table 1). Sapwood area from the monitored trees in the sap flux stations was used to compute tree transpiration. Sapwood 
area and tree density from the trees in the survey plots were used to scale tree-level transpiration to the watershed-level.

\subsection{Sap flux estimates}

One to five of each overstory tree species (loblolly pine, oak spp., tulip poplar, sweetgum, Virginia pine, and red maple) were instrumented with a heat dissipation sensor to measure sap flux in the riparian buffer, mid-hillslope, or upland-hillslope zones. In total, there were 68 monitored trees across the watershed. Each $20 \mathrm{~mm}$ sap flux sensor was installed 1.4 meters above the ground surface (i.e., at dbh) on the north face to avoid direct sun influence. Sensor signals were converted from temperature difference to tree sap flux density $\left(J_{\mathrm{s}}, \mathrm{g} \mathrm{cm}^{-2} \mathrm{day}^{-1}, \mathrm{~g}\right.$ sap $\mathrm{cm}^{-2}$ sapwood area day $\left.{ }^{-1}\right)$ for each overstory species according to the computation method outlined in Granier (1987).

American beech, hickory spp, black cherry (Prunus serotina), scarlet oak (Quercus coccinea), blackgum (Nyssa sylvatica), black oak (Quercus velutina), sourwood (Oxydendrum arboretum ), and shortleaf pine (Pinus echinata) accounted for only $8 \%$ of co-dominant canopy species and were not monitored at any of the three zones for transpiration due to limited field resources and long distance between trees. Red maple and tulip poplar were also not monitored at the upland-hillslope for the same reasons. Mean speciesspecific transpiration $\left(T_{s}\right.$, liters day $\left.{ }^{-1}\right)$ for these non-monitored trees was quantified based on a linear model developed from diameter at breast height $(\mathrm{dbh}, \mathrm{cm})$ and $T_{s}$ from monitored trees:

For 2015, $T_{s}=3.1^{*} \mathrm{dbh}-34, \mathrm{r}^{2}=0.76, \mathrm{p}<0.001$ (Eq. 1)

For 2016, $T_{s}=3.8^{*} \mathrm{dbh}-48, \mathrm{r}^{2}=0.70, \mathrm{p}<0.001$ (Eq. 2)

$T_{s}$ was then converted from liters day ${ }^{-1}$ to $\mathrm{mm} \mathrm{day}^{-1}$ (equivalent to liters $\mathrm{m}^{-2}$ day $^{-1}$ ) by dividing the total sap flow volume of the survey plot trees by plot area $\left(78.5 \mathrm{~m}^{2}\right)$.

Zone watershed-level transpiration $\left(T_{\mathrm{z}}, \mathrm{mm}_{\text {day }}{ }^{-1}\right)$ was estimated from tree-scaled $J$ for all monitored trees, estimates of $T_{\mathrm{s}}$ from the non-monitored trees (equation 1), stand density (tree counts), and species composition and sapwood area. The same species sapwood area and tree counts were used for each zone to scale $J_{\mathrm{s}}$ to $T_{\mathrm{z}}$ to avoid over- or under-emphasizing watershed sapwood area for each zone. Weighted area percentages for each zone was estimated based on landscape units that included percent slope, soil type, and unsaturated zone depth (Dreps et al., 2014) and field observations of species across the watershed (Boggs et al., 2015). The weighted area average (i.e., $10 \%$ buffer, $45 \%$ mid-hillslope, and $45 \%$ upland-hillslope) of $T$ z from each zone was then used to compute the average riparian buffer, mid-hillslope, and upland-hillslope $T$ w.

Measurements of tree $J_{\mathrm{s}}$ in the buffer have been continuous since 2010 as part of other studies (Boggs et al., 2015; 2016). However, monitoring in mid-hillslope and upland-hillslope did not begin until May 2015. Despite these two zones having only two months (November - December 2015) of non-growing season $J_{\mathrm{s}}$ data in 2015, average daily non-growing season $T_{\mathrm{w}}$ based on $J_{\mathrm{s}}$ from this limited dataset is representative of the longer-term non-growing record for Piedmont hardwoods ( $0.25 \mathrm{~mm}$ day $^{-1}$, Oishi et al., 2010). Therefore, we estimated the other four months (January - April 2015) of missing daily non-growing season $T$ w and filled other data gaps based on averaged daily $T_{\mathrm{w}}$ that was generated during the monitoring periods.

To correct for changes in sap flux density throughout the sapwood area, (as these changes can influence the relative comparisons of species sap flux density), we used the predictions of the radial profile of sap flux density with depth for each wood type from the gamma-type model in Berdanier et al., 2016. Based to their model, we developed correction factors for each species and tree anatomy/type. After the correction factor was applied to sap flux density, annual stand transpiration was computed. The trees in our study were smaller than the ones in the Berdanier et al., 2016 which means that the sap flux density corrections were likely not going to be large, and would become even smaller when corrected for the area represented by the outer $20 \mathrm{~mm}$ probes in relation to the other sections of the tree. The corrected transpiration values (sap flux density*sapwood area*correction factor) are reported in this manuscript. 


\subsection{Statistical analysis}

All data analyses were completed using JMP Pro 12 (JMP, 2012). Sap flux density across years and zones was determined using a paired t-test. The zone was defined as a riparian buffer, mid-hillslope, and uplandhillslope. The t-test was selected, and the significance level was set to $\alpha<0.05$ to determine which year or zone was statistically different from each other. The power model was used to determine the nonlinear relationship between daily VPD and sap flux density. The explanatory and response variables in the bivariate plots were log-transformed to produce the power model, $\mathrm{y}=\mathrm{ax} \mathrm{x}^{\mathrm{b}}$. The effects test was used to determine if the evaporative demand changed across the zones and if there was an interaction between VPD and the zones. VPD was log transformed to reflect the power function of the relationship between VPD and species sap flux density. $\mathrm{P}$ values $<0.05$ indicate that the independent variables and/or their interaction were significantly related to sap flux density.

\section{RESULTS}

\subsection{Rainfall and VPD}

Total annual precipitation was $1027 \mathrm{~mm}$ in 2015 and $1178 \mathrm{~mm}$ in 2016 (Figure 2a and b). The daily growing season (from May to October) precipitation ranged from 0.2 to $47.2 \mathrm{~mm}$ in 2015 (total growing season precipitation $=424 \mathrm{~mm}$ ), and 0.2 to $119.2 \mathrm{~mm}$ in 2016 (total growing season precipitation $=846$ $\mathrm{mm}$ ). These data contrasted with the average (2008-2016) growing season precipitation of $636 \mathrm{~mm}$, and the average annual total precipitation of $1112 \mathrm{~mm}$ (Boggs et al., 2016). Thus, the 2015 growing season was $34 \%$ drier than average with only $424 \mathrm{~mm}$ of precipitation, while the 2016 growing season was $33 \%$ wetter than average with $846 \mathrm{~mm}$.

Growing season VPD in the drier year of 2015 was significantly higher (p [?] 0.05) than the growing season VPD in the wetter year of 2016 (Figure 2c). In 2015, the mean daily growing season VPD averaged 0.73 (standard error, 0.028 ) $\mathrm{kPa}$ and ranged from 0.01 to $1.7 \mathrm{kPa}$. In 2016, the mean daily growing season VPD averaged $0.65(0.027) \mathrm{kPa}$ and ranged from 0.01 to $1.5 \mathrm{kPa}$.

\subsection{Soil moisture}

Although seasonal soil moisture was significantly higher in the riparian buffer than the other zones in 2015 and 2016 (Table 2), a more detailed analysis of daily soil moisture revealed that moisture varied across zones throughout the year (Figure 2a and b). For example, shallow soil moisture shifted from a wet state to a dry state halfway through the 2015 growing season in the riparian buffer. Shallow soil moisture also remained in a dry state until late September (i.e., mid-hillslope moisture was higher than riparian buffer moisture from July 2015 to September 2015).

Deep soil moisture $(30 \mathrm{~cm})$ in the riparian buffer remained higher than deep soil moisture in the mid-hillslope and upland-hillslope $(60 \mathrm{~cm})$ during the 2015 and 2016 growing seasons (Figure 2b). Soil moisture at this deeper depth in the riparian buffer also remained wet and reached a saturation point of $40 \%$ during the non-growing season. There were a few periods in the non-growing season where the deep soil moisture in the mid-hillslope and upland-hillslope was higher than the soil moisture in the riparian buffer.

\subsection{Sap flux density}

Daily growing season sap flux density $\left(J_{\mathrm{s}}\right)$ varied across species, zones, and years (Table 2$)$. In the zone vs zone comparison in 2015, the loblolly pine, sweetgum, Virginia pine, and white oak $J_{\mathrm{s}}$ in the riparian buffer were significantly higher than $J_{\mathrm{s}}$ in those same species in the mid-hillslope and upland-hillslope (Table 2). In contrast, the tulip poplar and red maple $J_{\mathrm{s}}$ in the riparian buffer were significantly lower than tulip poplar and red maple $J_{\mathrm{s}}$ in the mid-hillslope.

In the zone vs zone comparison in 2016, the loblolly pine was the only species where $J_{\mathrm{s}}$ in the riparian buffer was significantly higher than $J_{\mathrm{s}}$ in the mid- and upland-hillslopes (Table 2). The red maple and white oak $J$ s were not significantly different across zones. The tulip poplar and Virginia pine had significantly higher $J$ 
s on the mid-hillslope than did the same species in the riparian buffer. The mid-hillslope $J_{\mathrm{s}}$ in sweetgum trees were significantly higher than sweetgums located in the riparian buffer and upland-hillslope.

In the year vs year comparison, the loblolly pine, tulip poplar, and white oak were the only species where $J$ ${ }_{\mathrm{s}}$ did not change significantly. $J_{\mathrm{s}}$ is all other species increased or decreased from 2015 to 2016.

Growing season means showed that white oak $J_{\text {s }}$ trees were not significantly different across zones (Table 2). The $J_{\mathrm{s}}$ in loblolly pine, sweetgum, and Virginia pine decreased significantly across zones (riparian buffer $>$ mid-hillslope $>$ upland-hillslope) and decreased with decreasing soil moisture content (Table 2). $J_{\mathrm{s}}$ in tulip poplar and red maple increased significantly across zones (riparian buffer $<$ mid-hillslope) and increased with decreasing soil moisture content.

\subsection{Relationship between VPD, sap flux density, and zones}

A power function model was used to determine the relationship between the daily growing season (MayOctober) VPD and sap flux density from the monitored tree species in 2015 and 2016. Daily sap flux density in all species were significantly related to VPD across all zones in both years with the highest $\mathrm{r}^{2}$ values occurring in 2015 when compared to 2016 (Table 3). The nonlinear relationship generally led to increased deviations at higher VPD values.

\subsection{Relationship between zones, sapwood area, dbh, and tree-level transpiration}

Mean daily transpiration in the monitored trees ranged from 10 to $93 \mathrm{~L} \mathrm{day}^{-1}$ in 2015 and 9 to $122 \mathrm{~L} \mathrm{day}^{-1}$ in 2016 (Figure 3). Mean dbh ranged from 14 to $40 \mathrm{~cm}$, sapwood area ranged from 132 to $1000 \mathrm{~cm}^{2}$, and both were linearly related to transpiration in all zones in 2015 and 2016. The slope coefficients between zones were not significantly different (Figure 3$)$. When dbh and sapwood area were small $\left(<20\right.$ and $<400 \mathrm{~cm}^{2}$, respectively), daily transpiration ranged from 9 to $45 \mathrm{~L} \mathrm{day}^{-1}$. For trees with larger sapwood area (800 to $1000 \mathrm{~cm}^{2}$ ), daily transpiration ranged from 72 to $122 \mathrm{~L} \mathrm{day}^{-1}$.

\subsection{Watershed-level transpiration}

Growing season weighted watershed-level transpiration $\left(T_{w}\right)$ was similar in 2015 (i.e., $284 \mathrm{~mm}$ ) and 2016 (i.e., $285 \mathrm{~mm}$, Table 4). In contrast, the growing season watershed-level transpiration (by zone, $T_{\mathrm{z}}$ ) in the riparian buffer ranged from 334 to $363 \mathrm{~mm}$ while growing season $T_{\mathrm{z}}$ in the mid-hillslope ranged from 306 to $313 \mathrm{~mm}$. The growing season $T_{\mathrm{z}}$ on the upland-hillslope produced the lowest transpiration, $245 \mathrm{~mm}$ in 2015, and $246 \mathrm{~mm}$ in 2016. The daily growing season $T_{\mathrm{z}}$ in 2015 and 2016, respectively, averaged 1.7 (0.06) $\mathrm{mm} \mathrm{day}^{-1}$ and $1.4(0.06) \mathrm{mm}_{\text {day }}{ }^{-1}$, and reached a maximum of $2.6 \mathrm{~mm}$ day $^{-1}$ and $2.7 \mathrm{~mm} \mathrm{day}^{-1}$ in the riparian buffer, $1.2(0.05) \mathrm{mm} \mathrm{day}^{-1}$ and $1.0(0.05) \mathrm{mm}^{-1 a y^{-1}}$, and a maximum of $2.4 \mathrm{~mm}$ day $^{-1}$ and 2.5 $\mathrm{mm}$ day $^{-1}$ on the mid-hillslope, and $1.0(0.03) \mathrm{mm}_{\text {day }}{ }^{-1}$ and $0.9(0.03) \mathrm{mm}^{-1 a y^{-1}}$, and a maximum of 2.0 $\mathrm{mm} \mathrm{day}^{-1}$ on the upland-hillslope. There was also a strong seasonal component to $T$ win 2015 and 2016, where $80 \%$ (i.e., $284 \mathrm{~mm}$ ) and $79 \%$ (i.e., $285 \mathrm{~mm}$ ) of the stand transpiration occurred in the growing season. Regardless of which zone was used to derive $T_{\mathrm{w}}$, the non-growing season $T_{\mathrm{w}}$ was always statistically lower than the growing season $T_{\mathrm{w}}$ (Table 4 ).

The annual $T_{\mathrm{w}}$ was $361 \mathrm{~mm}$ in 2015, and $370 \mathrm{~mm}$ in 2016. In 2015 and 2016, loblolly pine accounted for $40-50 \%$, white oak 13-14\%, tulip poplar 11-14\%, sweetgum 6-7\%, Virginia pine 4-8\%, and red maple $4 \%$ of growing season $T_{\mathrm{w}}$ and $\mathrm{T}_{\mathrm{z}}$.

\section{DISCUSSION}

The heat dissipation method was used to determine several different indicators of water loss from the study watershed: species-specific sap flux density, tree-level transpiration, and watershed-level transpiration. Results from each indicator were compared across species, zones, and years. Even though in both years the different tree species accounted for the same proportion of watershed-level transpiration (around $45 \%$ for loblolly pine, $14 \%$ for white oak, $12 \%$ for tulip poplar and the other species representing less than $30 \%$ ), we found a large variability of sap flux over time, and among trees and spatial zones within the watershed. Such 
variabilities are essential for understanding environmental controls on tree transpiration, plant resilience to drought, and scaling up transpiration measurements from the tree level to stand and landscape scales.

\section{$4.1 J_{\mathrm{s}}$ across species and zones}

In the dry year, most species water use rates were sensitive to the topography, and their $J_{\mathrm{s}}$ values increased with increasing soil water availability in the zones (Table 2). For example, growing season $J$ s in loblolly pines in the riparian buffer was $14 \%$ higher than $J_{\mathrm{s}}$ in loblolly on the mid-hillslope and $65 \%$ higher than $J_{\mathrm{s}}$ in loblolly on the upland-hillslope. In addition, growing season $J_{\mathrm{s}}$ in white oak in the riparian buffer was 12 $\%$ higher than $J_{\mathrm{s}}$ in white oak on the upland-hillslope. By contrast, growing season $J_{\mathrm{s}}$ in tulip poplar and red maple in the riparian buffer was $12-13 \%$ lower than $J_{\mathrm{s}}$ in poplar and maple on the mid-hillslope. This suggests that tulip poplar and red maple may have utilized shallow soil water in the riparian buffer early in the growing season with no relative increase in transpiration rates when compared to the mid-hillslope zone, and may have been water-stressed later in the season as there was a sharp decline and wide fluctuations in soil moisture in the buffer when compared to the mid-hillslope (Hawthorne and Miniat 2016). In addition, there was likely enough energy and soil water in the soil profile for poplar and maple to maintain water use rates on the mid-hillslope during a period when mid-hillslope soil moisture was higher than the riparian buffer.

We observed a soil moisture shift from a wet state to a dry state halfway through the 2015 growing season in the riparian buffer, and soil moisture remained in a dry state until late September (i.e., mid-hillslope moisture was higher than riparian buffer moisture from July 2015 to September 2015). This depletion of soil water in the buffer zone likely reduced $J$ sin maple and poplar trees. This switch between wet and dry states in the buffer was not as pronounced in 2016, likely because it was a wet year. Thus, riparian buffer and mid-hillslope red maple $J_{\mathrm{s}}$ were not significantly different and not influenced by the topography in the wet year. In addition, $J_{\mathrm{s}}$ in white oak was statistically the same in the buffer and upland zones in the wet year, 96 vs. $101 \mathrm{~g} \mathrm{~cm}^{-2}$ day $^{-1}$, indicating no sensitivity to zones. Hawthorne and Miniat (2016) also found variations in species-based transpiration responses to climatic variation and topographic position, and they suggest that variability in species responses to drought may lead to complex shifts in species composition.

\section{$4.2 J_{\mathrm{s}}$ respond to $\mathrm{VPD}$}

Although $J_{\mathrm{s}}$ in all species were related to VDP (Table 3), it is worth noting that the relationships between growing season VPD and $J_{\mathrm{s}}$ in 2015 in the riparian buffer were stronger than in 2016 (i.e., higher $\mathrm{r}^{2}$ values), likely because the soils in the watershed were drier and the evaporative potential was significantly higher in 2015 than in 2016 (Domec et al., 2009). Growing season VPD in 2015 was significantly higher (by 5\%) than the long-term VPD average for the watershed, and growing season VPD in 2016 was significantly lower (by $10 \%$ ) than the long-term average (Boggs et al., 2016). The variation suggests that VPD likely compensated for any potential drought-induced reduction in $J_{\mathrm{s}}$ in 2015 for some species in this study, as would be supported by Oishi et al., (2010).

We found the interaction between VPD and zone was significantly related to $J_{s}$ in loblolly pine, sweetgum, and Virginia pine but not related in red maple, tulip poplar, and white oak (Table 5). Emanuel et al. (2010) reported that water stress conditions could decouple species $J_{\mathrm{s}}$ from VPD and become increasingly more dependent on soil moisture. Species specific transpiration responds differently to soil moisture depletion for several reasons including deep-water access even when shallow soil water is available (Oren and Pataki 2001; Lanning et al., 2020).

\subsection{Tree- and watershed-level estimates of transpiration}

Sapwood area explained nearly $85 \%$ of the variability in daily tree-level transpiration $\left(T_{s}\right)$ (in the monitored trees) across all zones, with tulip poplar generating higher than predicted transpiration for its diameter and sapwood area in the riparian buffer and mid-hillslope (Figure 3). In contrast, loblolly pine had lower than predicted transpiration for its sapwood area in the mid-slope and upland-slope. Unlike species $J_{\text {s }}$ that was related to zone, an effect test revealed that $T_{s}$ rates were significantly correlated to sapwood area and species 
but not to zone (sapwood $-\mathrm{F}$ ratio $122.8, \mathrm{P}=<0.0001$; species $-\mathrm{F}$ ratio 9.2, $\mathrm{P}=0.0076$; zone $-\mathrm{F}$ ratio 2.1, $\mathrm{P}=0.20$ ). This is not surprising as $T_{s}$ is closely linked to and driven largely by sapwood area (Wullschleger and Norby, 2001).

Annualized zone weighted watershed-level transpiration $\left(T_{\mathrm{w}}\right)$ was very similar from a dry year to a wet year (361 mm vs. $370 \mathrm{~mm}$, Table 4) in part because $J_{\mathrm{s}}$ was not significantly different for loblolly pine, white oak, and tulip poplar between years. These three species occupied $50 \%$ of the sapwood area and were responsible for almost $75 \%$ of the water loss in both years (i.e., $73 \%$ in 2015) and (i.e., $76 \%$ in 2016). Oishi et al. (2010) also found similarities or small variations in transpiration across wet and dry years, $329 \mathrm{~mm}$ to $349 \mathrm{~mm}$ over four years. Hawthorne and Miniat (2018) also found that species composition may explain the similarity between $T_{\mathrm{w}}$ between wet and dry years.

There were differences in scaled $T_{\mathrm{w}}$, depending on which scaled $T_{\mathrm{z}}$ was used to represent tree water use (Table 4). We compared $T_{z}$ based on scaled $J_{s}$ data from the buffer, mid-slope, and upland-slope against $T_{w}$ based on weighted $T_{z}$ from all three stations to determine their relative differences. Riparian buffer zone estimates of annual water loss were $24 \%$ higher in 2015 and $21 \%$ higher in 2016 than $T$ w based on weighted $\mathrm{T}_{z}$ from all three stations. Annual water loss from the mid-hillslope was only $2 \%$ higher in 2015 and 2016 than $T_{\mathrm{w}}$ based on weighted $T_{z}$ from all three stations while water loss from upland-hillslope was $7 \%$ lower in both years than $T_{\mathrm{w}}$. The riparian buffer and upland-hillslope produced larger percent differences than mid-hillslope likely because they did not fully capture the spatial changes in species $J$ s response to VPD as well as the range of watershed soil moisture conditions and stand structure across the watershed (Mitchell et al., 2012). In addition, the hydrologic controls on tree $J_{\mathrm{s}}$ in these two zones likely shifted from climatic factors to soil moisture as VPD increased, and soil moisture rapidly decreased (Emanuel et al., 2010). The riparian buffer and upland-hillslope zones also had larger amplitudes for drainage and soil moisture compared to the mid-hillslope. The coefficient of variation in soil moisture was $24 \%$ in the mid-hillslope, $32 \%$ in the riparian buffer, and $48 \%$ in the upland-hillslope. If we assume weighted $\mathrm{T}_{\mathrm{z}}$ across the three zones offered the best estimate of $T_{\mathrm{w}}$, then it appears $\mathrm{T}_{\mathrm{z}}$ from the mid-hillslope was within a reasonable range to determine annual $T_{\mathrm{w}} . J_{\mathrm{s}}$-scaled $T_{\mathrm{w}}$ from the buffer and upland-hillslope resulted in broader estimates of $T_{\mathrm{w}}$ than mid-hillslope and should probably not be used as standalone zones to $\operatorname{determine} T_{\mathrm{w}}$.

\section{CONCLUSIONS}

We found that the response in tree sap flux density to decreasing soil water content across zones was dependent on the species, year, and vapour pressure deficit, tree-level transpiration was strongly linked to sapwood area, and mid-slope sap flux density will likely provide the best estimate for ET. In the dry year, species sap flux density in loblolly pine, sweetgum, Virginia pine, white oak decreased from the buffer zone to the upland-slope. In contrast, sap flux density in red maple and tulip poplar increased from the buffer zone to the mid-slope, primarily due to increased atmospheric evaporative demand.

Water use by trees could intensify soil hydrological drought (i.e., lack of soil moisture) during short-term dry periods of low precipitation. Under normal climatic conditions, red maples and tulip poplars will likely create more soil water storage and benefit storm water abatement when compared to other common trees in the region. However, the advantages of these species might be less critical during increasing or prolonged droughts.

This study improves our broader understanding of the relationship between species-specific transpiration and soil moisture. Linking soil moisture, tree water use, and climatic variability at the watershed level is rarely done, but is critical to refining transpiration estimates, managing the effects of drought, and understanding hydrological processes in unmanaged and managed watersheds across various regions. New plantations are being planned across the southern United States to meet the rising demand for wood production. Findings from this project could help public and private landowners decide which trees might be better to maximize the benefits and costs related to water in tree planting across the Piedmont.

\section{ACKNOWLEDGEMENTS}


This research was funded by the United States Department of Agriculture Forest Service Eastern Forest Environmental Threat Assessment Center. We would like to thank the many students and support staff that has been involved with this project over the years for their diligent work in the field and laboratory. We would also like to especially thank the North Carolina Forest Service Forestry Nonpoint Branch for their project support and guidance regarding the Best Management Practices in this watershed, and the two anonymous dedicated reviewers for improving the early version of the manuscript. Appreciation is expressed to North Carolina State University for their partnership and cooperation in providing access to their respective forestlands to conduct this study.

\section{REFERENCES}

Berdanier, A. B., Miniat, C. F., \& Clark, J. S. (2016). Predictive models for radial sap flux variation in coniferous, diffuse-porous and ring-porous temperate trees. Tree Physiology : tpw027-. 10 p. 10.1093/treephys/tpw027

Boggs, J. L., Sun, G., Jones, D., \& McNulty, S. G. (2013). Effect of soils on water quantity and quality in Piedmont forested headwater watersheds of North Carolina. Journal of the American Water Resources Association (JAWRA) , 49(1), 132-150. https://doi.org/10.1111/jawr.12001

Boggs, J., Sun, G., Domec, J-C., McNulty, S. \& E. Treasure. (2015). Clearcutting upland forest alters transpiration of residual trees in the riparian buffer zone. Hydrological Processes , 29, 4979-4992. DOI: $10.1002 /$ hyp.10474

Boggs, J., Sun, G., \& McNulty, S. G. (2016). Effects of Timber Harvest on Water Quantity and Quality in Small Watersheds in the Piedmont of North Carolina. Journal of Forestry , 114, 27-40. DOI: http://dx.doi.org/10.5849/jof.14-102

Bosch, D. D., Marshall, L. K., \& Teskey, R. (2014). Forest transpiration from sap flux density measurements in a southeastern Coastal Plain riparian buffer system. Agricultural and Forest Meteorology, 187, 72-82. 10.1016/j.agrformet.2013.12.002

Brantley, S. T., Miniat, C. F., \& Bolstad, P. V. (2019). Rainfall partitioning varies across a forest age chronosequence in the southern Appalachian Mountains. Ecohydrology , 12(4), e2081-. https://doi.org/10.1002/eco.2081

Cleland, D. T., Freeouf, J. A., Keys Jr, J. E., Nowacki, G. J., Carpenter, C. \& McNab, W. H. (2007). Ecological Subregions: Sections and Subsections of the Conterminous United States [1:3,500,000] [CD-ROM]. Sloan, A.M., cartog. Gen. Tech. Report WO-76D. Washington, DC. United States Department of Agriculture, Forest Service, 1.

Domec, J-C., Noormets, A., King, J. S., Sun, G., McNulty, S. G, Gavazzi, M. J., Boggs, J. L. \& Treasure E. A. (2009). Decoupling the influence of leaf and root hydraulic conductances on stomatal conductance and its sensitivity to vapor pressure deficit as soil dries in a drained loblolly pine plantation. Plant, Cell and Environment , 32, 980-991. DOI: 10.1111/j.1365-3040.2009.01981.x

Domec, J-C., Sun, G., Noormets, A., Gavazzi, M. J., Treasure, E. A.., Cohen, E., Swenson, J. J.., McNulty, S. G., \& King, J. S. (2012). A comparison of three methods to estimate evapotranspiration in two contrasting loblolly pine plantations: age-related changes in water use and drought sensitivity of evapotranspiration components. Forest Science, 58(5), 497-512. http://dx.doi.org/10.5849/forsci.11-051

Dreps, C., James, A. L., Sun, G., \& Boggs, J. (2014). Water Balances of Two Piedmont Headwater Catchments: Implications for Regional Hydrologic Landscape Classification. Journal of the American Water Resources Association , 50(4), 1063-1079. DOI: 10.1111/jawr.12173

Emanuel, R. E., Epstein, H. E., McGlynn, B. L., Welsh, D. L., Muth, D. J., \& D’Odorico, P. (2010). Spatial and temporal controls on watershed ecohydrology in the northern Rocky Mountains. Water Resources Research , 46(11), 1-14. https://doi.org/10.1029/2009WR008890 
Emanuel, R. E., Riveros-Iregui, D. A., McGlynn, B. L., \& Epstein, H. E. (2011). On the spatial heterogeneity of net ecosystem productivity in complex landscapes. Ecosphere, 2(7), 1-13. https://doi.org/10.1890/ES1100074.1

Ford, C. R., Laseter, S. H., Swank, W. T., \& Vose, J. M. (2011). Can forest management be used to sustain water-based ecosystem services in the face of climate change? Ecological Applications , 21(6), 2049-2067. https://doi.org/10.1890/10-2246.1

Granier A. (1987). Evaluation of transpiration in a Douglas-fir stand by means of sap flow measurements. Tree Physiology , 3, 309-320.

Hawthorne, S., \& Miniat, C. F. (2016). Topography may mitigate drought effects on vegetation along a hillslope gradient. Ecohydrology , 11(1), 1-11. https://doi.org/10.1002/eco.1825

JMP, 2012. Version 12. SAS Institute Inc., Cary, NC, 1989-2012.

Lanning, M., Wang, L., Benson, M., Zhang, Q., \& Novick, K. A. (2020). Canopy isotopic investigation reveals different water uptake dynamics of maples and oaks. Phytochemistry , 175, 112389. https://doi.org/10.1016/j.phytochem.2020.112389

Li, C., Sun, G., Cohen, E., Zhang, Y., Xiao, J., McNulty, S. G., \& Meentemeyer, R. K. (2020a). Modeling the impacts of urbanization on watershed-scale gross primary productivity and tradeoffs with water yield across the conterminous United States. Journal of Hydrology , 583, 124581-. https://doi.org/10.1016/j.jhydrol.2020.124581

Li, C., Sun, G., Caldwell, P. V., Cohen, E., Fang, Y., Zhang, Y., Oudin, L., Sanchez, G. M., \& Meentemeyer, R. K. (2020b). Impacts of urbanization on watershed water balances across the conterminous United States. Water Resources Research , 56(7), 1-19. https://doi.org/10.1029/2019WR026574.

Liu, N., Dobbs, G. R., Caldwell, P. V., Miniat, C. F., Bolstad, P. V., Nelson, S., \& Sun, G. (2020). Quantifying the role of State and private forest lands in providing surface drinking water supply for the Southern United States. Gen. Tech. Rep. SRS-248. Asheville, NC: U.S. Department of Agriculture Forest Service, Southern Research Station. 405 p. https://doi.org/10.2737/SRS-GTR-248.

Mitchell, P. J., Benyon, R. G., \& Lane, P. N. J. (2012). Responses of evapotranspiration at different topographic positions and catchment water balance following a pronounced drought in a mixed species eucalypt forest, Australia. Journal of Hydrology , 440, 62-74. doi:10.1016/j.jhydrol.2012.03.026

Moore, G. W., Bond, B. J., Jones, J. A., Phillips, N., \& Meinzer, F. C. (2004). Structural and compositional controls on transpiration in 40- and 450-year-old riparian forests in western Oregon, USA. Tree Physiology , 24, 481-491. DOI: 10.1093/treephys/24.5.481

Moore, G.W., Orozco, G., Aparecido, L. M. T., \& Miller, G. R. (2017). Upscaling transpiration in diverse forests: Insights from tropical premontane site. Ecohydrology, 11(3) e1920. https://doi.org/10.1002/eco.1920.

North Carolina Geological Survey. (1988). Preliminary explanatory text for the 1985 geologic map of North Carolina. Contractual Report,88-1, 1-162.

Oishi, A. C., Oren, R., Novick, K. A., Sari, P., \& Katul, G. G. (2010). Interannual Invariability of Forest Evapotranspiration and Its Consequence to Water Flow Downstream. Ecosystems , 13, 421-436. https://doi.org/10.1007/s10021-010-9328-3

Oren, R., \& Pataki, D. E. (2001). Transpiration in response to variation in microclimate and soil moisture in southeastern deciduous forests. Oecologia , 127, 549-559. https://doi.org/10.1007/s004420000622

Poyatos, R., Víctor G., Víctor F., Mark A. A., Balázs A., David A., Marcos P. M. A., Boggs, J. L., Sun, G. \& et al. (2020). Global transpiration data from sap flow measurements: the SAPFLUXNET database.Earth System Science Data Discussions , 1-57. https://doi.org/10.5194/essd-2020-227. 
Rummer, R. B. \& Hafer, M. L. (2014). Outlook for Piedmont forests: a subregional report from the Southern Forest Futures Project. Gen. Tech. Rep. SRS-GTR-195. Asheville, NC: USDA-Forest Service, Southern Research Station. 84 p.

Sun, G., McNulty, S. G., Shepard, J. P., Amatya, D. M., Riekerk, H., Comerford, N. B., Skaggs, W., \& Swift, L., Jr. (2001). Effects of timber management on the hydrology of wetland forests in the Southern United States. Forest Ecology and Management , 143, 227-236. https://doi.org/10.1016/S0378-1127(00)00520-X

Sun, G., Caldwell, P., Noormets, A., McNulty, S. G., Cohen, E., \& et al. (2011). Upscaling key ecosystem functions across the conterminous United States by a water-centric ecosystem model. Journal of Geophysical Research . 116, 1-16. DOI: 10.1029/2010JG001573

Sun, G., Domec, J-C., \& Amatya, D. M. (2016). Forest evapotranspiration: measurements and modeling at multiple scales. In: Amatya et al. (eds.). Forest Hydrology: Processes, Management and Assessment . CABI Publishers, U.K. 32-50.

Swank, W.T. \& Vose, J.M. (1994). Long-term hydrologic and stream chemistry responses of southern Appalachian catchments following conversion from mixed hardwoods to white pine. In Hydrolgie kleiner Einzugsgebiete: Gedenkschrift Hans M. Keller, R. Landolt (ed). Schweizerische Gesellschaft fur Hydrologie und Limnologie, Bern, Switzerland, 164-172.

Vose, J. M., Ford Miniat, C., Luce, C. H., Asbjornsen, H., Caldwell, P. V., Campbell, J. L.,.. \& \& Sun, G. (2016). Ecohydrological implications of drought for forests in the United States. Forest Ecology and Management , 380, 335-345. https://doi.org/10.1016/j.foreco.2016.03.025

Wear, D. N., \& Greis, J. G., eds. (2013). The Southern Forest Futures Project: technical report. Gen. Tech. Rep. SRS-GTR-178. Asheville, NC: USDA-Forest Service, Southern Research Station. 542 p.

Wullschleger, S. D., \& Norby, R. J. (2001). Sap velocity and canopy transpiration for a 12year-old sweetgum plantation exposed to free-air CO2 enrichment. New Phytologist , 150, 489-498. https://doi.org/10.1046/j.1469-8137.2001.00094.x

Yi, K., Dragoni, D., Phillips,R. P., Roman, D. T., \& Novick, K. A. (2017). Dynamics of stem water uptake among isohydric and anisohydric species experiencing a severe drought, Tree Physiology , 37(10), 1379- 1392, https://doi.org/10.1093/treephys/tpw126

\section{Hosted file}

Figures_revised2.pptx available at https://authorea.com/users/410803/articles/520042variability-of-tree-transpiration-across-three-zones-in-a-southeastern-u-s-piedmontwatershed

\section{Hosted file}

Tables_revised2.pptx available at https://authorea.com/users/410803/articles/520042variability-of-tree-transpiration-across-three-zones-in-a-southeastern-u-s-piedmontwatershed 